Mihratsiina sytuatsiia v Ukraini [The migrational situation in Ukraine]. Political thought. No.8. pp. $45-72$. [in Ukrainian].

4. Prybytkova, I. (2011). Suchasni mihratsiini protsesy: teoretyko-metodolohichni aspekty doslidzhen [Modern migration processes: theoretical and methodological aspects of research. Sociology: theory, methods, marketing]. Sociology: theory, methods, marketing. Kyiv, No.1, pp. 161 - 172. [in Ukrainian].

5. Trubych, S. (2009). Mihratsiini protsesy i zainiatist naselennia [Migration processes and employment]. Journal of Lviv National University. Series: International relations. Lviv, vol.1, pp. 398 - 403. [in Ukrainian].

6. Homra, A.U. (1999). Migracija naselenija: voprosy teorii, metodiki issledovanija [Population migration: questions of theory, research methods]. Kyiv, 148 p. [in Russian].

7. Sheliuk, V. (2001). Sotsialna mihratsiia: Etapy, funktsii, typy [Social migration: Stages, functions, types]. Perspectives, No. 3 (15), pp. 46-47. [in Ukrainian].

8. Availableat:https://www.google.com/url?sa $=t \&$ source=web\&rct=j\&url=https://www.oecd.org/els/mig/ RUSSIAN.pdf\&ved=2ah UKEwiCvKiX1 YHiAh VwpYsK HepZCi gQFjAAeg QIBRAC \&usg= AOvVaw26UTOeAt1ndqdcVLNFfs7

9. Available at: http://miok.lviv.ua/wp-content/ uploads/2015/03/zvitpj.pdf(38)

10. Geist, B. (2002). Sociologicky slovnik [Sociological dictionary]. 580 p. [in Polish].

Стаття надійшла до редакції 04.06.2020

УДК 373.3.016:004

DOI:

Іван Василиків, кандидат педагогічних наук, старший викладач кафедри математики, інформатики та методики їх викладання у початковій школі Дрогобицького державного педагогічного університету імені Івана Франка

\title{
ПРОПЕДЕВТИКА КУРСУ “ІНФОРМАТИКА” В ПОЧАТКОВІЙ ШКОЛІ
}

У статті проаналізовано необхідність вивчення інформатики, починаючи з молодчого шкільного віку; розглядаються цілі, які поставлені перед учителем та учнями при вивченні інформатики в початковій цколі. Проведення уроку із застосуванням IT вимагає від вчителя як власних навичок ефективного використання IT, так і знань методів застосування циих технологій у початковій школі, а також санітарно-гігієнічних вимог і вікових особливостей учнів. Комп 'ютерна підтримка вивчення базових предметів вимагає для практичної реалізації изього процесу відповідної підготовки вчителів початкових класів засобами IT.

Ключові слова: інформатика; початкова школа; наступність навчання; IT; інформачійна культура.

Jim. 10.

Ivan Vasylykiv, Ph.D.(Pedagogy), Senior Lecturer of the Mathematics, Informatics and Methods of Teaching in Primary School Department Drohobych Ivan Franko State Pedagogical University

\section{PROPEDEUTICS OF THE COURSE "INFORMATICS" IN PRIMARY SCHOOL}

The article deals with the necessity of studying of computer science, starting from primary school age; the goals set for the teacher and students in the study of computer science in primary school are considered. Conducting a lesson with the use of IT requires from the teachers both their own skills of effective use of IT, and knowledge of methods of application of these technologies in primary school, as well as sanitary and hygienic requirements and age characteristics of students. Computer support for the study of basic subjects requires for the practical implementation of this process the appropriate training of primary school teachers.

In modern conditions, the following tendencies can be distinguished: the teacher is increasingly free from some didactic functions, in particular control, leaving behind creativity; his/her role changes significantly, and the possibilities of managing the cognitive activity of students expand; qualitative characteristics of educational activity change, new didactic functions are transferred to information technologies (presentation of educational information, demonstration of processes and phenomena); the requirements for computer training of teachers are growing.

The information and communication support of the educational process develops the visual, effective, intuitive, creative types of student thinking; communication skills; forms the ability to make optimal decisions or propose the solutions in difficult situations; develops skills of self-education and self-control; lays the foundations of information culture and the beginnings of information processing skills.

Keywords: Computer Science; Elementary School; continuity of training; IT; information culture.

П

остановка проблеми. Наша дійсність диктує свої умови для комфортного і успішного “вливання" дітей у доросле життя. У постіндустріальному світі, в якому ми 3 вами живемо, існує чітка необхідність у тому, що люди могли $з$ легкістю здійснювати всі необхідні 


\section{ПРОПЕДЕВТИКА КУРСУ “ІНФОРМАТИКА” В ПОЧАТКОВІЙ ШКОЛІ}

дії з інформацією: пошук, обробку, зберігання, а також своєчасну передачу актуальної та достовірної інформації.

Прищеплення цих навичок більшою мірою необхідно зпочинати в ранньому шкільному віці, поступово спочатку переводячи звички в навички, доводячи їх до автоматизму, а потім - в стійкі знання. Як це здійснюється 3 навчанням дітей математики, письма та читання в початковій школі, і потім, закріпленню цих навичок у старшій школі.

Аналіз останніх досліджень і публікацій. У сучасній початковій освіті існують такі основні напрями навчання інформатики в початкових класах, залежно від мети та завдань, які визначають їх відповідний зміст.

Основним завданням першого напряму $є$ використання сучасних IT при вивченні більшості предметів програми початкової школи [7, 70]. Такий підхід досить вдало реалізований у курсі “Сходинки до інформатики” (Ф. Ривкінд, Г. Ломаковською, С. Колесніковим, Й. Ривкіндом). На думку авторів, основним використанням комп'ютерних засобів навчання $\epsilon$ їх органічна інтеграція у певні уроки. Основна функціональна мета - загальний розвиток дитини, її пам'яті, просторової уяви, логічного мислення, творчості. Авторам експериментального курсу вдалося у цікавій, ігровій формі реалізувати поступове оволодіння учнями комп'ютерними інструментами, набуття ними базових навичок використання пристроїв вводу-виводу, керування комп'ютером тощо.

Мета статті полягає у висвітленні етапів та аналізу особливостей упровадження пропедевтичного курсу “Інформатика" в освітній процес початкової школи.

Виклад основного матеріалу. На сьогоднішній день комплекс “Сходинки до інформатики” містить 33 навчально-розвивальні програми різного обсягу та рівня складності [1, 42].

Для курсів другого напряму характерне формування змісту освіти на основі конкретних предметних цілей. Пропедевтичні курси 3 інформатики в цій галузі покликані розвивати практичні навички роботи з IКТ та теоретичною інформацією, але їхні обсяг і тематика різні.

Другий напрям, на відміну від першого, наголошує не лише на необхідності розвитку різних навичок роботи з комп'ютером та певних програмних продуктів, а й надає можливість молодшим школярам отримати базові знання 3 інформатики, що розширить їх світогляд та створить основу для подальшого вивчення предмету “Інформатика".
Особливістю пропедевтичних курсів інформатики третього напряму є розвиток інтелектуальних, естетичних, творчих здібностей та підвищення пізнавальної активності дитини [7, 70-71].

Таким чином, важливою складовою навчального процесу в початковій школі виступає формування комфортного інформаційного та комунікаційного середовища, яке включає в себе на обов'язковому рівні не тільки інформаційні об'єкти і зв'язки між ними, а й кошти, технології, що забезпечують збір, обробку, передачу та зберігання інформації.

Як за кордоном, так і в Україні, дискусії, що розпочались у 80-х р. минулого століття і тривають майже донині, щодо заборони використання комп'ютерів у 1 - 4-тих класах, мотивовані, головним чином, турботою про здоров'я учнів. Вважається недоречним навіть використовувати термін “інформатика” для початкової школи [6].

Перешкода полягає у тому, що вчителі початкових класів не знають, як працювати 3 новими інформаційно-комунікаційними технологіями, і не розуміють, як їх можна використовувати на уроках з різних предметів.

Тому для підвищення кваліфікації вчителів початкової школи пропонуються віртуальні лекції та приклади щодо використання IT у викладанні інших наук (наприклад, http://ecs. lewishan.gov. uk/ talent /pricor/module4.html (СШA), www. szenarien.educa.ch (Швейцарія), http:// stefanov. ict4kids.org (Болгарія), підвищення кваліфікації на дистанційних курсах через Інтернет (наприклад, www.szenarien.educa.ch (Швейцарія) тощо [9].

Ще одна проблема, яка заважає пропедевтиці інформаційної культури в початковій школі, полягає у тому, що більшість учнів не розуміють справжнього призначення інформаційних технологій, оскільки сприймають їх як іграшки.

Польські вчителі розв'язали цю проблему, створивши інтегрований курс інформатики. Наприклад, для першого класу цього курсу передбачено [12]:

на першому етапі:

1) поєднання 3 мовним компонентом: вдосконалення навичок письма, а саме: вивчення літер клавіатури, складання слів і фраз, складання запрошень;

2) вивчити правила комп'ютерної безпеки;

3) вивчити призначення апаратного забезпечення комп'ютера: призначення миші, клавіатури, монітора, системного блоку;

4) вивчення геометричних фігур: побудова різних фігур за допомогою програм графічного редагування; 
5) виконання математичних задач на комп'ютері;

6) малювання: робота з програмами графічного редагування;

7) музика: створення звуків та музики за допомогою комп'ютерних програм;

на другому етапі:

1) використання комп'ютерних послуг: великі та малі літери, форматування тексту; використання символів, розділових знаків під час друку на комп'ютері; вміння працювати 3 текстовими та графічними редакторами;

2) обробка текстів та малюнків: використання символів, знаків для ілюстрації текстів; додавання таблиць до текстів, робота 3 таблицями; створення презентацій з використанням елементів графіки та текстів;

3) створення малюнків: малювання елементарних малюнків, геометричних фігур, вибір та зміна кольорів;

4) застосування комп'ютерних програм: створення анімації та мелодії за допомогою Edytorze та Logomocji;

5) використання комп'ютера як засобу комунікації.

З одного боку, наше суспільство, функціонуючи в цьому середовищі, вносить до нього зміни, які впливають на нього, з іншого ж - науковотехнічний прогрес також вносить в інформаційне середовище свій вклад, вдосконалюючи передовсім технічний бік інформаційнокомунікаційного середовища, що тягне за собою зміну взаємин у суспільстві між їх учасниками в усіх вікових групах: дорослих, підлітків або молодших школярів [2].

Сучасний світ ставить перед освітою завдання не тільки виховати гуманну людину, а й сформувати якості майбутнього професіонала, 3 вільним володінням інформаційними технологіями [10].

Актуальним виступає питання визначення, в якому віці потрібно починати вивчення інформатики учням як предмету в школі. Сьогодні рекомендується починати вивчення предмету "Інформатика" відповідно до наступного розподілу за курсами:

1. Пропедевтичний курс інформатики (початкова школа та 5-6 класи середньої загальноосвітньої школи);

2. Базовий курс інформатики (7-9 класи середньої загальноосвітньої школи);

3. Профільний курс (10-11 класи середньої загальноосвітньої школи) [5].

Для кожного тимчасового періоду вивчення інформатики виділені значимі цілі, які можна сформулювати наступним чином: на пропедевтичному курсі здійснюється ознайомлення учнів 3 комп'ютером, що дає змогу сформувати основу інформаційної культури:

- вивчення інформатики на базовому рівні передбачає, що учні оволодіють навичками володіння комп'ютером в навчальній і професійній діяльності;

- i, нарешті, профільний курс, метою якого є продовження вивчення курсу інформатики на більш високому рівні.

Вивчення інформатики в початковій школі спрямоване на досягнення таких цілей, як:

1. Навчити учнів працювати $з$ інформацією: здійснювати іiї пошук, аналіз, обробку, передачу та зберігання.

2. Формування комп'ютерної грамотності та інформаційної культури.

3. Підготовка учнів до подальшого вивчення інформатики, знайомство 3 фундаментальними знаннями основ інформатики, тобто з основними поняттями, до яких належать такі поняття, як: інформація, об'єкт, алгоритм.

4. Формування цілісної картини можливостей персонального комп'ютера, до яких відносять: можливість малювати, обчислювати, писати; можливість збереження інформації в пам'яті комп'ютера, представленої у вигляді малюнка або символів; можливість передачі інформації; можливість пошуку необхідної інформації [3].

Таким чином, якщо розглядати основні цілі вивчення курсу інформатики в початковій школі, то їх можна представити у такий спосіб:

1. Розвиток логічного мислення, спрямоване на розвиток здібностей приймати рішення, i формування умінь мислити послідовно і зважливо.

2. Розвиток алгоритмічного мислення.

3. Розвиток системного мислення, тобто вміння визначати і вибудовувати відносини між об'єктами.

4. Формування комп'ютерної грамотності.

5. Підвищення рівня інформаційної культури.

Отже, виховання інформаційного світогляду це основна мета, яку ставить перед собою пропедевтичний курс інформатики, тобто підготовка молодших школярів до вміння працювати з великими обсягами інформації [8].

Можна зробити висновок, грунтуючись на тому, що метою початкового навчання є формування стійкого фундаменту для подальшого навчання, що інформатика в початковій школі, на пропедевтичному етапі навчання, може бути розглянута в контексті двох позицій:

1. Формування необхідних і достатніх знань про інформаційну діяльність людини. 
2. Уміння розв'язувати завдання за допомогою комп'ютера та інших засобів інформаційних та комунікаційних технологій, тобто здійснювати пошук, обробку, передачу та зберігання інформації [11].

Інформатика може не просто захопити дітей, а й дати їм можливість вивчення шкільних предметів з новою боку, так, наприклад: вивчення текстового редактора на уроці інформатики може сприяти виробленню вміння грамотно писати тексти, формулювати думки; вивчення технології пошуку необхідної інформації спонукає дітей пізнавати навколишній світ. Розширювати кругозір i, як наслідок, формувати особистісні якості такі, як самостійність і творчість; вивчаючи на уроках інформатики графічний редактор, в учнів розвивається образне і логічне мислення. Таким чином, можна сказати, що інформатика тісно пов'язана з іншими предметами шкільного курсу початкової школи, допомагаючи учням у процесі навчання [4].

Інформатика виконує складну функцію, 3 одного боку, навчаючи учнів необхідних знань 3 предмету, 3 іншого боку, мотивує учнів застосовувати отримані знання в процесі вивчення інших предметів шкільного курсу.

Рівень знань, якими повинні оволодіти учні початкової школи, передбачає регулярне вивчення інформатики як самостійного уроку в навчальному плані, інформатика як окремий предмет в початковій школі не виділений в самостійний предмет. Вона вивчається частково в рамках декількох дисциплін: математики технології та інших.

Висновки. Отже, можна зазначити, що пропедевтика курсу “Інформатика” в початковій школі це не тільки важлива складова навчального процесу загалом, але й достатня і необхідна робота $з$ учнями для того, щоб сформувати необхідні за стандартом знання і вміння, i, обов'язково, забезпечити наступність інформатики при переході учнів 3 початкової школи в середню ланку.

\section{ЛІТЕРАТУРА}

1. Андрусич О. Комп’ютерна підтримка курсу “Сходинки до інформатики”: зроблено перший крок. Початкова школа. 2006. № 7. С. 41-43.

2. Биков В. Ю., Лапінський В. В. “Методологічні та методичні основи створення і використання електронних засобів навчального призначення". Комп ’ютер у школі та сім'ї. 2012. № 2. С. 362.

3. Власій О. О., Дудка О. М., Кібірєва Л. М. “Особливості розробки програмного забезпечення для початкової та середньої школи". Комп'ютерно-інтегровані технології: освіта, наука, виробниитвво. 2015. вип. 19. С. 182-188.

4. Гриневич Л., Елькін О., Калашнікова С. “Нова українська школа : концептуальні засади реформування середньої школи”. URL: http:// mon.gov.ua.

5. Гуржій А. М., Лапінський В. В. “Електронні освітні ресурси як основа сучасного навчального середовища загальноосвітніх навчальних закладів". Інформаційні технологї̈ в освіті. 2013. № 5. С. 30-37.

6. Жалдак М.І., Рамський Ю.С. Проект стандарту освітньої галузі інформатики. Київ: Генеза, 1997. С. 48-59.

7. Кивлюк О. Аналіз наукових досліджень 3 проблематики пропедевтики інформатики в початковій школі. Інформатика та інформачійні технології в навчальних закладах. 2006. № 6. C. 69-72.

8. Лаврентьєва Г. П. “Здоров’язбережувальні вимоги до застосування електронних засобів навчального призначення". Інформаційні технологї $i$ засоби навчання. 2011. № 2 (22). URL: http://www.journal.iitta.gov.ua.

9. Литвинова С. Г. “Особливості розробки критеріїв оцінювання електронних освітніх ресурсів”. Наукові записки. Випуск 4, Серія: Проблеми методики фізико-математичної $i$ технологічної освіти. Кіровоград: РВВ КДПУ ім. В. Винниченка. Частина 1. 2013. С. 63-67.

10. Мельник, О. М. "Проектування електронних освітніх ресурсів 3 математики для учнів початкової школи": дис. канд. пед. наук. Київ, 2017.

11. Микитюк О. М., Олефіренко Н. В., Янц Н. Д. “Технологія проектування електронних дидактичних ресурсі”. Засоби навчальної ma науково-дослідної роботи. вип. 40. 2011. С. 141 153.

12. Witold Kranas, Wanda Jochemczyk, Iwona Krajewska-Kranas, Agnieszka Samulska, Miroslawem Wyczolkowskim. Program nauczania informatyki w szkole podstawowej "Lekcje z komputerem". Warszawa 2004. 52 s.

\section{REFERENCES}

1. Andrusych, O. (2006). Kompiuterna pidtrymka kursu "Skhodynky do informatyky": zrobleno pershyi krok [Computer support of the course "Steps to Informatics: the first step]. Elementary school. No. 7. pp. 41-43. [in Ukrainian].

2. Bykov, V. Yu. \& Lapinskyi, V. V. (2012). "Metodolohichni ta metodychni osnovy stvorennia i vykorystannia elektronnykh zasobiv navchalnoho pryznachennia"["Methodological and methodological 
bases of creation and use of electronic means of educational purpose"]. Computer at school and family. No. 2. pp. 3-62. [in Ukrainian].

3. Vlasii, O. O., Dudka, O. M. \& Kibirieva, L. M. (2015). "Osoblyvosti rozrobky prohramnoho zabezpechennia dlia pochatkovoi ta serednoi shkoly" ["Features of software development for primary and secondary schools"]. Computer-integrated technologies: education, science, production. Vol. 19. pp. 182-188. [in Ukrainian].

4. Hrynevych, L., Elkin, O. \& Kalashnikova, S. "Nova ukrainska shkola : Kontseptualni zasady reformuvannia serednoi shkoly" ["New Ukrainian School: the conceptual principles of Secondary School reformation"]. Available at: http://mon.gov.ua. [in Ukrainian].

5. Hurzhii, A. M. \& Lapinskyi, V. V. (2013). ["Elektronni osvitni resursy yak osnova suchasnoho navchalnoho seredovyshcha zahalnoosvitnikh navchalnykh zakladiv" ["Electronic educational resources as the basis of the modern educational environment of secondary schools"]. Information technology in education. No. 5. pp. 30-37. [in Ukrainian].

6. Zhaldak, M.I. \& Ramskyi, Yu.S. (1997). Proekt standartu osvitnoi haluzi informatyky [Draft of standard of educational branch of Informatics]. Kyiv. pp. 48-59.[in Ukrainian].

7. Kyvliuk, O. (2006). Analiz naukovykh doslidzhen z problematyky propedevtyky informatyky $\mathrm{v}$ pochatkovii shkoli [An analysis of scientific research on the problems of propaedeutic of computer science in primary school]. Informatics and information technologies in educational institutions. No. 6. pp. 69-72. [in Ukrainian].

8. Lavrentieva, H. P. (2011). "Zdoroviazberezhuvalni vymohy do zastosuvannia elektronnykh zasobiv navchalnoho pryznachennia" ["Health saving requirements for the use of electronic learning tools"]. Information technologies and teaching aids. No. 2 (22). Available at: http://www.journal.iitta.gov.ua. [in Ukrainian].

9. Lytvynova, S. H. (2013). “Osoblyvosti rozrobky kryteriiv otsiniuvannia elektronnykh osvitnikh resursiv" [Peculiarities of development of criteria for evaluation of electronic educational resources "]. Proceedings. Kirovohrad. part1. pp. 63-67. [in Ukrainian].

10. Melnyk, O. M. (2017). "Proektuvannia elektronnykh osvitnikh resursiv z matematyky dlia uchniv pochatkovoi shkoly" ["Design of electronic educational resources in mathematics for primary school students"]. Candidate's thesis. Kyiv. [in Ukrainian].

11. Mykytiuk, O. M., Olefirenko, N. V. \& Yants, N. D. (2011). "Tekhnolohiia proektuvannia elektronnykh dydaktychnykh resursi" ["Technology of designing the electronic didactic resources"]. Means of educational and research work. Vol. 40. pp. 141153. [in Ukrainian].

12. Witold Kranas, Wanda Jochemczyk, Iwona Krajewska-Kranas, Agnieszka Samulska, Miroslawem Wyczolkowskim (2004). Programnauczania informatyki w szkole podstawowej "Lekcje z komputerem" [Elementary School Informatics Curriculum "Computer Lessons"].Warszawa. 52 p. [in Poland].

Стаття надійшла до редакції 11.08.2020

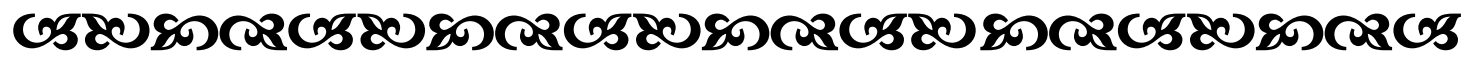

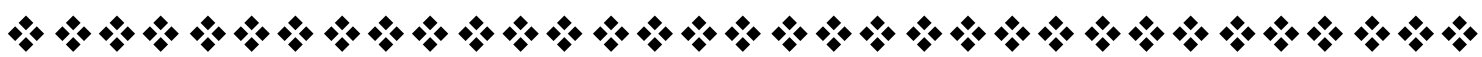

"Виіться у вчора, живіть сьогодні, сподівайтеся на завтра. Толовне - не припиняти задавати питання ... Ніқоли не втрачайте священної допитливості".

Альберт Ейнштейн

один із засновниқів сучасної теоретичної бізики, лауреат Нобелівської премії 3 бізикu

"Якщо бажасте досягти в житті успіху, зробіть наполегливість своїм қращим другом, досвід - мудрим радниқом, обережність-стариим братом, а надію - ангеломхоронителем".

Dжозебб Еддісон англійський письменникесеїст, драматург, публіиист та політичний діяч

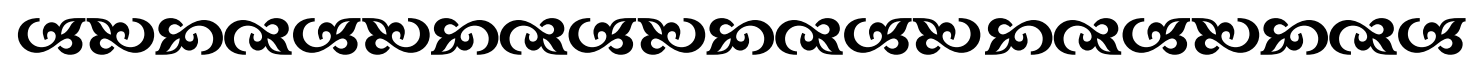

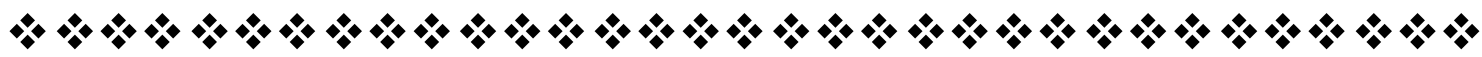

